\title{
Challenges of Return Migration to the Republic of Moldova in the Context of International Migration Flow
}

\author{
Mihai HACHI ${ }^{1}$, Stela MOROZAN ${ }^{2}$, Marina POPA ${ }^{3}$
}

\begin{abstract}
Return migration is one of the types of contemporary migration, gaining momentum in many countries of the world as a result of frequent economic, political and social conjunctural changes that have influenced migration as a phenomenon. As part of the migration process, return migration has been less studied, given the low intensity of this form of migration and the difficulty of quantifying returned migrants. The return and reintegration of returned migrants, regardless of the reason or the mode of return, is a challenge both for returnees and for the authorities of the receiving countries and requires action plans, well thought-out strategies in order to manage this process effectively and to encourage new flows of returnees. Through this study, the authors wish to analyse the phenomenon of return migration through the prism of its determining factors, to follow the effectiveness of instruments that stimulate the return migration, to analyse the experience of European countries in managing this type of migration as best practices.The use of classical and contemporary human geography research methods will allow the quantitative and qualitative assessment of return migration, the study being based on a sociological survey conducted with returnees following a migration experience.
\end{abstract}

Key words: return migration, migratory ebb, return programs

JEL Code: J01, J11, J15

\section{Introduction}

Migration is one of the most far-reaching social processes that have shaped the lives of millions of people around the world. Practically all

\footnotetext{
${ }^{1}$ Mihai Hachi, PhD, associate professor of the Business International Department, Faculty of International Economic Relations, ASEM, https://orcid.org/0000-0001-6631-6495, hachi.mihail.gheorghe@ase.md

${ }^{2}$ Stela Morozan, PhD student, ASEM, morozanstela@gmail.com

${ }^{3}$ Marina Popa, PhD, associate professor of the Business International Department, , ASEM. https://orcid.org/0000-0001-7668-2309, popa.marina.vasile@ase.md
} 
countries in the world are involved in the migration process, regardless of their status as migrant-receiving or migrant-donor states. Migration as a bidirectional phenomenon has developed with different intensity in time and space, influenced by a number of socio-economic and political factors. Migration flows have grown throughout history, diversifying and expanding in terms of spatial coverage, reaching a peak after the Second World War with the strong emergence of long-distance transport systems and the liberalisation of the movement of human flows. Eastern European countries were involved in an intense migration process in the period after the $1990 \mathrm{~s}$, as political emancipation and socio-economic crises marked by systemic transformations led to the creation of large flows of migrants, who took the foreign route as a route to survival. The Republic of Moldova is one of the countries most affected by the migration phenomenon, with the population involved in various forms of migration, including return migration.

Over time and through different migration experiences, several countries of the world have changed their status from emigration states to immigration states, and in the current context of the global pandemic, a return of migrants is expected in the context of economic recessions that are acutely felt in countries with large numbers of migrants. This change in status is relevant for the countries of southern Europe, which were transformed from countries of emigration into countries of immigration in the $1980 \mathrm{~s}$, their attractiveness increasing as they reached economic maturity. The return of migrants to their country of origin could also be caused by the increasingly active transfer of economic activities to developing countries with low labour costs, thus remote work being an option for a growing number of firms in rich countries, but with high living costs. This ebb in the flow of migrants, mostly from former out-migrants, could be an important resource for the economies of countries in transition, which are dependent on the volume of remittances sent home, but also on acute human and labour shortages, as in the case of Moldova. This type of migration is currently attracting the attention of researchers and decision-makers because of the role it could play in the demographic and economic development of countries, as returnees could serve as a catalyst for the development of human, financial and social innovative capital. These premises formed the basis of the study, and the authors proposed a number of objectives. These include: 
- $\quad$ identifying the role of return migration in the migration system;

- $\quad$ justifying the optimistic and pessimistic views on return migration

- $\quad$ assessing the degree of involvement of the Moldovan authorities in addressing return migration;

- $\quad$ identifying the problems and expectations of the returned compatriots after a migration experience, as well as understanding the challenges and opportunities regarding reintegration, transfer of human, social and financial skills acquired abroad to the country's economy (based on the sociological study);

- $\quad$ analysis of best practices in European countries in monitoring and managing returned migrants.

Return migration is a more recent phenomenon in the Republic of Moldova and therefore there are few empirical studies that would provide a clear answer to all the challenges of return migration. According to NBS data, the number of returnees after a migration experience is $2-3 \%$ of the total number of departed people, which cannot yet speak of a clear trend in this regard (ILO, 2017). The same situation is noted in the few sociological studies on return migration in the Republic of Moldova like Popova, Cheianu. (Popova et al, 2007; Cheianu-Andrei, 2013; ANOFM, 2018). Return migration can be found in a number of international studies: the comparative study of migrants returning from the Caribbean to France and the UK (Byron \& Condon, 1996); the experience of migrants returning from the United States to southern Italy (Cerase, 1974); empirical evidence of returned migrants in the UK (Dustmann \& Weiss, 2007); the experience of migration management in Bulgaria (Bakalova \& Misheva, 2018; Ivanova, 2015), etc.

\section{Data and Methodology}

Several methods were at the base in the making of this article: comparative, analytical, quantitative, statistical, survey. The quantitative method was implemented with the instrumentation of the sociological questionnaire. Anonymous questionnaires, questionnaires that were not completed entirely, and questionnaires of respondents who did not have more than half a year of residence abroad, were not analysed. To argue the issue of the return migration as a whole, we implemented the quantitative method, with the instrumentation of the sociological questionnaire among people 
returning to the country after a migration experience. The empirical study "Return migration" was conducted between January 15 and February 17, 2021, being launched in Romanian and Russian on the social networks Facebook and Odnoklassniki to obtain information related to the issue of the return migration. The questionnaire has 15 questions and was addressed to people who have lived/worked abroad for more than six months and currently are returning to the country. It was distributed to 85 people who were willing to take the survey in the online version. The aim of launching and conducting the sociological survey was to obtain information about returned migrants from the primary source, beyond official statistics, and to test several theoretical hypotheses about return migration. The share of people who completed the questionnaire was $63 \%$ women and $37 \%$ men, $3 \%$ of the respondents being over 60 years old, $25 \%$ aged between 40 and 60 years, $72 \%$ being between 18 - 40 years. $64 \%$ of the respondents declared themselves married, 19\% unmarried, $11 \%$ divorced, 3\% - widows/widowers. Four sociodemographic criteria weighted the data. The questionnaire was approved by Idata (a national company specialised in conducting nation wide surveys).

\section{Return migration - literature rewiev}

Among the new forms of manifestation of migration is return migration.

The definition of return migration has met several formulations, which include: ebb migration, migration home, re-emigration, return flow, migration for the second time, repatriation, transient migration, "retromigration", etc.

Return migration is considered by several authors as the final part of the migration cycle, and some recent studies show us that, the return of the migrants may be just another step in the migration cycle since people are constantly in search of better work and living opportunities" (Riiskjaer \& Nielsson, 2008; Stefannson, 2006).

According to King ,, Return migration can be defined as the process by which people return to their country or place of origin after a significant period in another country or region" (King, 2000). However, King does not specify what a ,,significant period" would entail. There are debates about the duration of the migration act to be considered a migrant and a return migrant. 
The return of migrants to their country of origin is a feature encountered in international migration, but it intensified during the period of globalization of human flow in the second half of the twentieth century. According to Gmelch ,1/4 of those over 16 million European emigrants to the USA later returned to their country” (Gmelch, 1980). ,, More than 1/2 of immigrants that arrived in the UK at the beginning of the 21st century return to their homeland after a period of 5 years" (Dustmann \& Weiss, 2007).

Migrants are often bothered by the uncertain status in the country of adoption. They try to obtain full membership in a different society, this process involving a difficult transformation from a "foreign" person to a "local" one. This transformation is difficult, even after naturalization, the returned migrant could always be perceived as a foreigner. In another study by the scientist (Boccagni, 2011), is noted the idea, according to which, some migrants returned to their country of origin, believe that their return is " $a$ restoration of the natural order of things".

The Organisation for Economic Co-operation and Development (OECD, 2008) identifies the returning migrant as ,people who return to their country of citizenship after being international migrants (short-term or longterm) in another country and who intend to stay in their own country for at least one year".

The United Nations (UN) identifies two categories of people entering a country: citizens and foreigners (1998). Citizens returning to the country after a period of staying abroad can be identified in several categories:

- people returned from work experience abroad;

- people returned after graduation and / or professional training;

- people returned after working abroad as international civil servants;

- people deported from abroad.

Immigrants based on humanitarian reasons: 1) refugees; 2) asylum seekers (UNDESA, 1998). The analysis of certain aspects of return migration can be found in the works of some authors from the Republic of Moldova too (Hachi \& Morozan, 2021; Vremiş, 2014).

\section{Return migration in the context of migration theories}

With the increasing significance of the migratory flow in the opposite direction, return migration has been the subject of different scientific 
interpretations and approaches, even if the explanation and understanding of this form of migration did not always coincide with the expectations of decision makers in the return countries of the migrants. Perhaps this is also the reason why the migration policies of the states of the world aim, for the most part, at emigration and much less at immigration with the segment of migrants returning from a migration experience.

This is due not so much to the lack of interest in the ebb and flow of migration as to the absence of reliable quantitative data on return migrants, which is difficult to quantify. There is now a growing emphasis in international migration institutions on reviewing approaches to return migration in the context of the migration-development relationship.

This critical review focuses on theories that have attempted to propose a set of explanatory variables aimed at better understanding the extent, dynamics of return migration, determinants, degree of reintegration in the migrant's country of origin, etc.

In the context of this study, it seems appropriate to review the main explanatory theories of return migration, taking into account the situation of this migration flow in the Republic of Moldova.

The manifestation of return migration can be inferred from explanatory theories of migration. Among the laws considered essential to the act of population migration, according to the geographic researcher E. Ravenstein, any migration flow produces a counter-flow. Migration as a process develops gradually: village-town-outward migration, migration in the opposite direction. The main reason for emigration is economic and this is also the basic reason for the return migration, if the economic situation in the emigrant's country improves or the emigrant's expectations for higher earnings abroad are not fulfilled (Ravenstein, 1885, Todaro, 1969).

To the extent that the neoclassical approach to international migration is based on ,the explanation of wage differentials between receiving and sending areas, and on migrants' expectations of higher earnings in host countries, return migration seems to be viewed as the result of a failed migration experience that did not achieve the expected benefits" (Todaro, 1969). Return occurs as a result of failed experiences abroad or because their human capital has not been rewarded as expected. From the neoclassical 
perspective, return migration involves labour migrants who miscalculated the costs of migration and did not obtain the benefits of the expected gains.

Moreover, unlike the new economics of labour migration, the neoclassical economics of migration views migrants as individuals who maximise not only their earningsbut also the length of their stay abroad in order to achieve permanent settlement and family reunification. In this framework of analysis, cost-effectiveness cannot be motivated by a failed migration experience in terms of expected earnings, employment and duration. On the contrary, while the neoclassical approach to return migration argues that migrants have not successfully maximised their expected earnings, the new economics of labour migration, views return migration as the logical outcome of a 'calculated strategy', defined at the level of the migrant's household and resulting from the successful achievement of objectives or targets.

In fact, as Stark argues, the new economics approach to labour migration shifts "the focus of migration theory from individual to general independence" (Stark, 1991), which means it involves the family or household level. Moreover, he sees the return as the natural outcome of a successful experience abroad, during which migrants have achieved their goals (i.e. higher incomes and accumulation of savings), while naturally remitting some of their income to the household. Remittances are an integral part of a strategy to diversify household resources to better compensate for the risks associated with the absence of an efficient insurance market in the migrant's home country. They are an explanatory factor in the decision to return home.

The new economics of labour migration, claims that people move temporarily to achieve their goals or targets in receiving countries as a prerequisite for returning home, return migration is seen as a success story, if not a logical outcome. Migrants have defined clear strategies before, during and after their migration experiences. The length of stay abroad is calculated according to household needs in terms of insurance, purchasing power and savings. Once these needs are met, return migration takes place. In other words, the new economy approach to labour migration for return migration is "beyond a reaction to the wage gap between the migrant's two destinations" (Stark, 1996).

Another approach to return migration analyses the act of return not only as a personal problem, but also as a social and contextual one, affected by situational and structural factors. The finality of migration, according to 
structuralists, whether analysed from the perspective of success or failure refers not only to the individual experience of the migrant but also to social and institutional factors in the country of origin. The success or failure of returnees is analysed by linking the 'reality' of the economy of the country of origin and society to the expectations of return.

Several authors try to explain the phenomenon of return migration in terms of migrants' aspirations, expectations and needs. Thus Cerase, F. (Cerase, 1974) identifies four different causes of return migration:

- the return from failure;

- the return from conservatism;

- return to retirement;

- return for innovation.

Some of these reasons are also indicated by the respondents who answered the sociological questionnaire. The general optimistic state of the returned migrants and the specific mentality of their compatriots do not reflect the reasons for the failure and/or conservatism of the returned Moldovan migrants. Most of them mentioned family as the main reason for their return (see Figure 2 below).

The typology of returnees is clearly an attempt to show that situational or contextual factors in the homeland must be taken into account as a prerequisite for determining whether a return experience is a success or a failure.

A few years later, in another relevant study with reference to return migration, the intention to return is correlated with their motivations (Gmelch, 1980). The intention to return, whether actual or intended, shapes the expectations of returnees to their homeland (Callea, 1986).

The structural approach to return migration focuses on the extent to which returnees may or may not have an impact on their home society upon return. Their analytical framework refers to the consequences that return migration may generate in the country of origin, with reference to two variables: time and space. Time refers to the length of stay abroad and the change that took place before and after migration, with reference to the status of returnees and the origin of their society. Social changes in the societies of origin as well as professional advancement are central to the return process of returnees. This readjustment process takes time, depending on the length of the migration experience at the same time, the length of stay abroad needs to be 
optimised to allow migrants to acquire and diversify their skills with the intention of investing them in the home country after return (Dustmann, 2001).

According to R. King, the length of the migrant's stay abroad is important for returning migrants „to use their newly acquired skills and attitudes for the benefit of their country of origin. It should be neither too short nor too long for the migrant to absorb certain experiences and values that could bring them back home', (King, 1986).

In terms of space, structuralists argue that the area of settlement (rural or urban) determines the return process of returnees and reshapes their expectations. Eventually, according to structuralists, ,,as returnees adapt their expectations and behaviours to local societies, they tend to orient their consumption patterns towards non-productive investment and visible consumption" (Byron \& Condon, 1996).

Thus, return migration can be based on different interpretations, which can be attributed as optimistic and pessimistic, allowing a better understanding of the phenomenon of return migration and can be analysed on behalf of the returned migrant and the migrant's state of origin, from the perspective of success or failure (Table 1).

Table 1. Return migration from the perspective of the migrant and the state of origin

\begin{tabular}{|c|c|}
\hline Optimistic perspective/success & Pesimistic perspective/failure \\
\hline \multicolumn{2}{|c|}{ The returning migrant } \\
\hline $\begin{array}{l}\text { - } \\
\text { social and cultural advantages in the } \\
\text { - country of origin } \\
\text { business development/business } \\
\text { investment opportunities } \\
\text { - } \text { transferable knowledge } \\
\text { - the desire for change in the country } \\
\text { of origin } \\
\text { - } \\
\text { - } \text { ramily and kinship ties } \\
\text { - receiving the inheritance } \\
\text { retirement }\end{array}$ & $\begin{array}{ll}\text { - } & \text { migration failure } \\
\text { - } & \text { conservatism } \\
\text { - } & \text { unrealised expectations } \\
& \text { integrate problems/failure to } \\
\text { - } & \text { poor health } \\
\text { - } & \text { encouraging emigration }\end{array}$ \\
\hline \multicolumn{2}{|c|}{ The migrant's state of origin } \\
\hline $\begin{array}{ll}\text { - } & \text { fulfilment of human potential } \\
\text { - } & \text { migrants' professional experience } \\
\text { - } & \text { acummulations transformed into } \\
\text { investments }\end{array}$ & - reintegration costs \\
\hline
\end{tabular}

Source: adapted from quoted sources and answers from the "Return Migration" questionnaire 


\section{Return migration: the European experience}

At EU level, the free movement of individuals is a basic principle granted and protected by several fundamental acts and agreements. However, allowing the free flow of people facilitates migration, which leads to significant social and economic problems in less developed regions. At European level, the free movement of people enhances competitiveness, while at national, regional and local level it can create unwanted tensions. The causes and consequences related to migration may differ from country to country and region to region; it is therefore difficult to develop a single policy 'formula' (Zwania-Rößler \& Ivanova, 2013).

At European level, the promotion of the single market and European mobility is a basic principle articulated in several policy documents, guidelines and acts since the 1957 Treaty of Rome.

The Single European Act, the Maastricht Treaty and the creation of Economic and Monetary Union were all important steps towards a unified labour market. The Lisbon Treaty 2009 institutionalised the common immigration and asylum policy, but focused exclusively on migration from third countries . The Single Market Act II highlighted the vision of a truly unified European labour market that could enhance Europe's competitiveness. The Lisbon Treaty specified that the EU should develop a common migration policy (dealing not only with security issues but also aiming to effectively coordinate migration flows to and within the EU).

In terms of the methods/instruments applied (e.g. re-attraction, reintegration, re-employment, detention) the European policies of the states show great variations and interpretations. Most documents apply several methods. In general, migrant resettlement plays a major role in most policies, but it is emphasised more in those resettlement policies that have clear economic objectives and in policies formulated in Eastern and South-Eastern European countries (e.g. Poland, Hungary and Albania). The latter seek to overcome the negative consequences of past migration, mainly due to income disparities. The role of re-employment is important in labour market interventions (Momentum in Hungary or Slovensko Calling in Slovakia).

The most significant migration policy instruments that would be suitable to returning migrants are the European Return Policies. To attract back skilled labour by offering grants. Grants are usually co-funded by the 
EU. Some examples: Rientro cervelli ("Brain buster") in Italy, Lendület ("Momentum") in Hungary or Slovensko Calling in Slovakia. Another tool used is the provision of information services for potential re-migrants on jobs, business opportunities, etc. An example of this is Poland, which has set up crisis centres to facilitate the flow of information and support the reemployment of returning migrants. Other examples include:

- help with reintegration and re-employment of migrants through recognition of skills obtained abroad (Romania);

- assistance at the return of the migrants who lost their jobs abroad and became homeless (BARKA Foundation, Poland);

- consolidating migrants' identity to motivate their return (Back2BG in Bulgaria);

- promotion of national culture and language abroad (e.g. Wspólnota Polska Association of Polish emigrants);

- creation of a database for collecting information on students and workers abroad (State Agency for Bulgarians Abroad), etc.

Although EU law does not allow restrictive administrative regulations on the movement of persons, there are examples of restrictive measures. In 2012, the Hungarian government introduced a new rule for future university students to slow down the migration of skilled labour. According to the new rules, students must work in Hungary for a period of time equal to their governmentfunded university education. If they emigrate, they have to pay the costs of their education. The decision to return is influenced not only by the policies implemented by migrant-sending countries, but also by receiving countries. In this sense, the following can be included:

- Pay-to-go programmes motivate return migration (used in Spain, Czech Republic, Denmark). Receiving countries offer money to migrants to facilitate their return to their homeland;

- Microcredit funds for returning migrants (e.g. Fondo Microcredito Balcani in Italy, helping Romanian migrants to return) in the context of cooperation between countries of origin and host countries.

\section{Migration in the view of returnees}

In order to obtain primary information on return migration, a sociological questionnaire "Return Migration" was launched on social media, 
given the current situation marked by the global pandemic. Through this survey, authors aimed to obtain answers to several questions related to returnees, which were formulated in 15 open questions. The answers were generalised, allowing to identify the reasons for their return, common problems faced by returned migrants, expectations and future intentions.

Of the returned respondents who completed the questionnaire, $67 \%$ had been abroad for more than 2 years, $10 \%$ - indicated a stay of 1 to 2 years, and $22.5 \%$ - up to 1 year. Most respondents returned within the last 3 years (2021 - 25\%, $2020-37.5 \%, 2019-8.8 \%$ of returnees) [According to the survey results, the countries of residence]. The global health pandemic situation has accelerated the return process for most people, especially for those who intended to return.

The countries of residence of Moldovan migrants who completed the questionnaire are: Italy (16.3\%), Russian Federation (13.8\%), UK (12.5\%) France and Germany (8.8\%), Israel, Romania (7.5\%), USA, United Arab Emirates (5\%), Greece (3.8\%), Iraq (1.3\%) ) [According to the survey results, the countries of residence]. The responses were generalised, allowing us to identify the reasons for returning to the country, common problems faced by returning migrants, expectations and future intentions, etc.

When asked about the reason for going abroad, respondents gave an answer close to empirical studies carried out in the country (Figure 1).

\section{Figure 1. The reason for migrants going abroad}

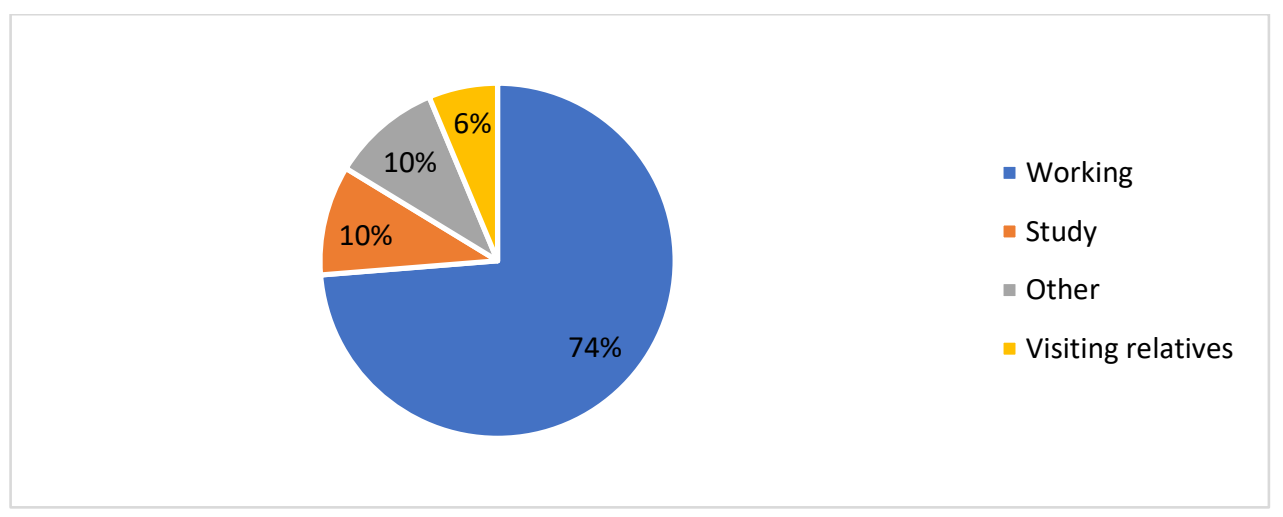

Source: survey data „, Return migration” 
Migration for work is the main reason for the migration of older people of working age. Even if the biometric passport does not allow employment in EU countries, Moldovan citizens take advantage of circular migration, which allows temporary employment, especially in households. For Moldovan citizens with Romanian citizenship, employment and residence in EU countries is legal and actively exploited. The economic factor determines the choice of destination of the migrant, the attractive salary opportunities and the high security offered by the EU Member States have determined the change of migration direction from the CIS to the EU Member States. Italy is the first destination among the EU Member States (\%), followed by Spain, Portugal among the respondents.

Migration for studies is a traditional type of migration for young people from the Republic of Moldova. It represents $10 \%$ in the study, and a specific model of migration for studies is currently being created. The main destinations of study migration for young people from Moldova are Romania, Italy, France, Czech Republic and Poland. After completing their studies most of them opt for further activity in the countries where they obtained their degree, a part of them, as shown by the survey results, return home, especially those schooled in Romania. Among the reasons for returning home, the majority of respondents indicated returning to their families (Figure 2).

\section{Figure 2. Reasons for the return of the migrants to the country}

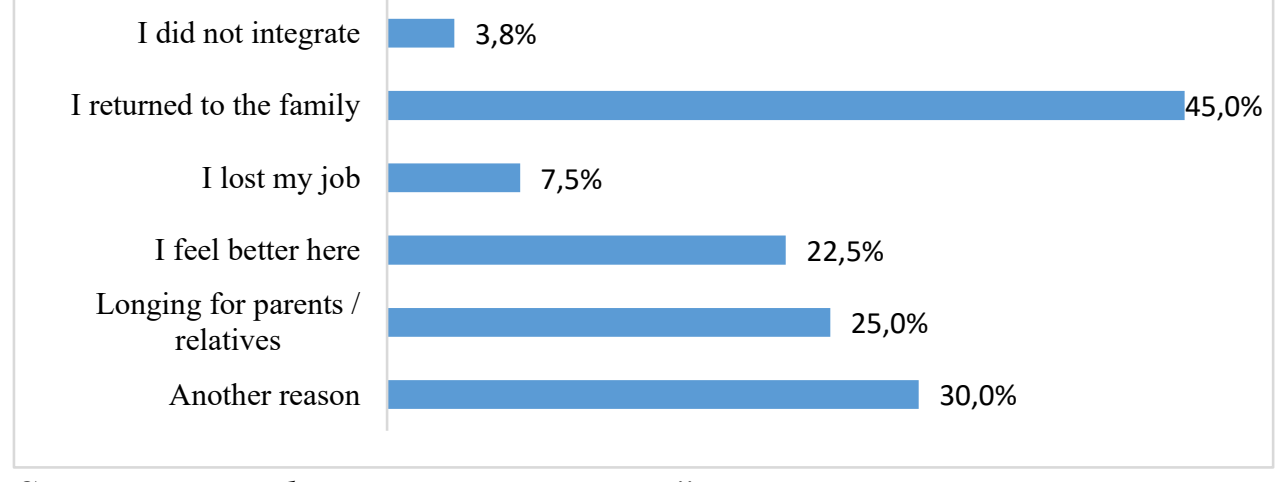

Source: survey data „Return migration”

The results of the study demonstrate the difficulty of adapting and integrating into new societies, especially for people over 40 . The reason of 
the return is mainly linked to the psycho-emotional comfort offered by the native country and family relationships. Returning to the Republic of Moldova, in most cases, the majority of respondents see it as a long-term perspective. Another reason is the retirement age, but these people will not complete the labour market in the country.

On another question about the problems that returned migrants have encountered about 1/3 indicate no problems at all (Figure 3).

More respondents point to adaptation as a problem of return $(27.5 \%)$, finding a job (25\%), integration into society/community (12.5\%). In this respect, the state authorities must take action and help returning migrants through reconciliation, correct information and programs for the integration of returning citizens. The programs offered aim more at making the most of migrants' savings and less at counselling or reintegrating them, as the study shows. The return of migrants to their homes could slow down the rate of population decline and the ageing of the population, especially in rural areas.

Figure 3.The nature of the problems faced by returning migrants

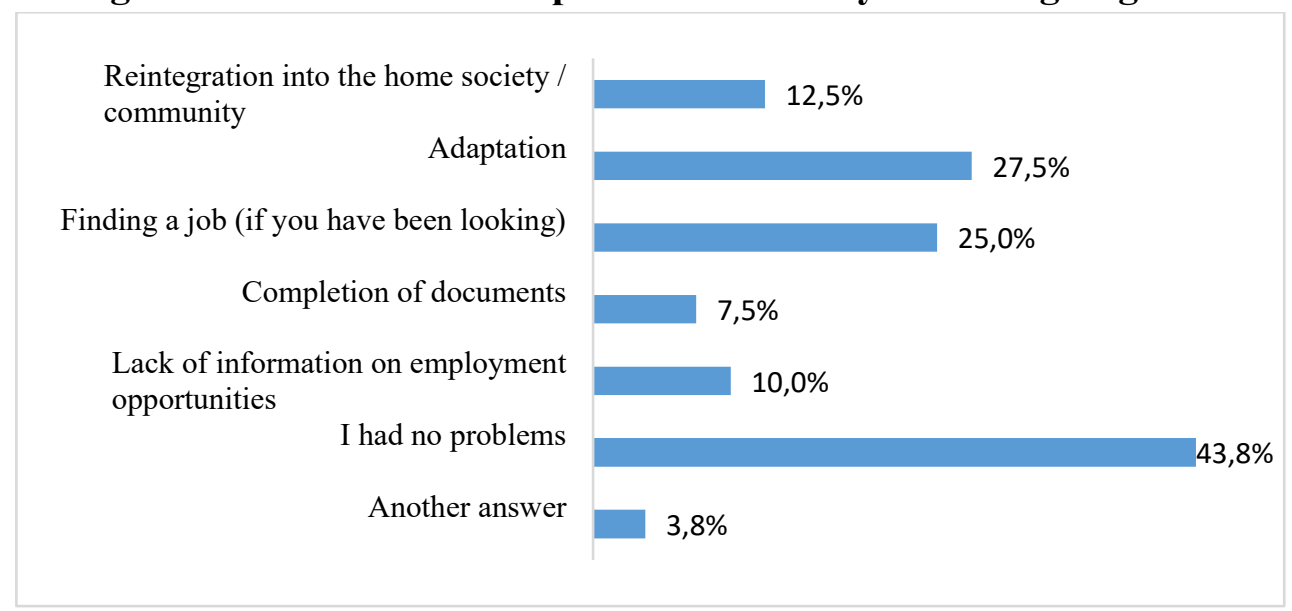

Source: survey data ,Return migration”

This study demonstrates the need to encourage return migration for the benefit of migrants and society as a whole. In this context, programs for returnees are imperative. When asked what kind of help they would expect from the state, they asked for better information about employment $(46.3 \%)$, assistance in starting a business (42.5\%), retraining (37.5\%) (Figure 4). 


\section{Figure 4. Support measures requested by returning migrants from state}

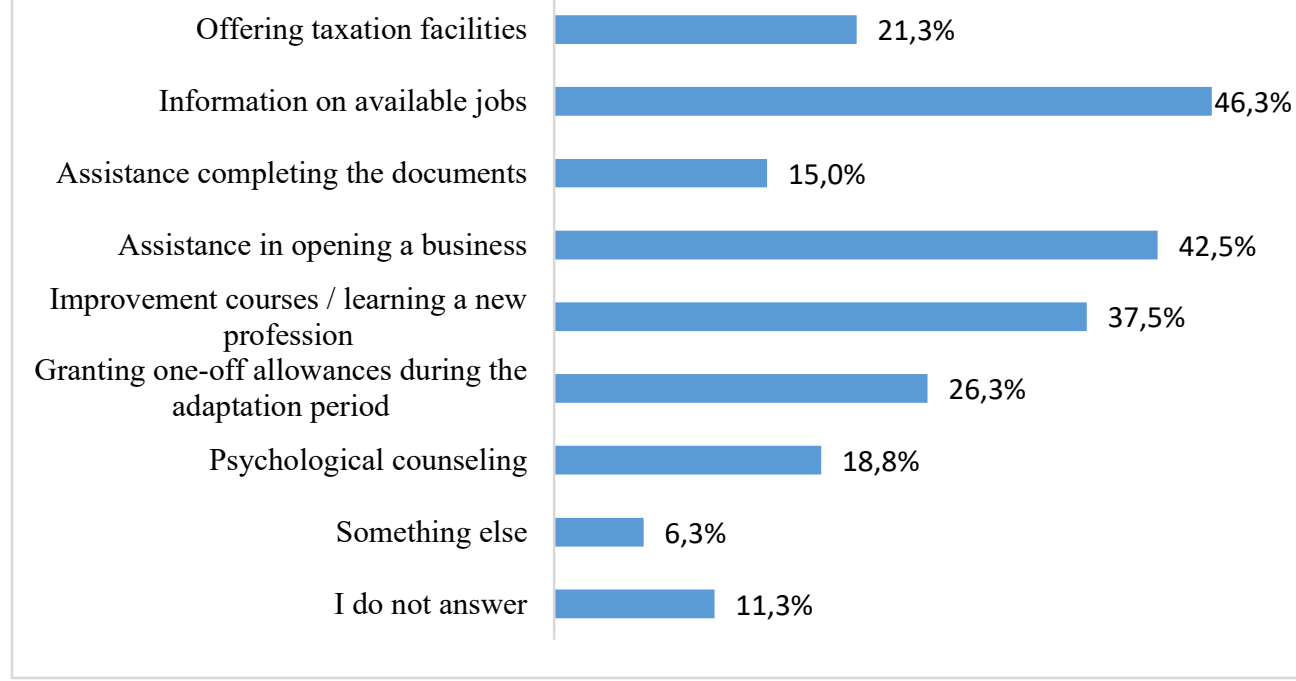

Source: survey data ,, Return migration”

Once back home, most citizens try to invest their savings at home. At the same time, the lack of reforms in various areas, bureaucracy and the longrunning economic crisis are putting a brake on people's desire to return home.

\section{Conclusions}

Return migration is a part of the migration process and requires a complex approach, an efficient management, in the interest of returnees and the state of origin. The return process is dynamic and complex and depends on the migrants' work capacity, relationships in society, family, living conditions, experience abroad etc.

Returning migrants could be an important resource for the economy of countries in transition, such as the Republic of Moldova, which is facing a labour shortage to ensure economic reforms in the context of the current transformations. Although the number of returnees is still quite small, the progress of economic reforms, adjusted by the stability and quality of governance would boost the segment of citizens willing to return to the country. 
The expectations of migrants returned to the Republic of Moldova are partially fulfilled, their integration and adaptation is left to the migrants, because the state authorities are insufficiently involved.

Returned migrants need support from state authorities for resettlement, including organisational and financial assistance, support for restoring their professional potential in their country of origin, as well as the implementation of assistance programmes for returnees, following the experience of European countries.

\section{References:}

Agenția Națională a Forței de Muncă [ANOFM], (2018). Raport de activitate ANOFM pentru anul 2017. https://anofm.md/files/elfinder/ANOFM $\% 20$ final $\% 20 \% 281 \% 29$.pdf

Bakalova, M., Misheva M. (2018). Explanations of Economic Rationality Challenged: contemporary return migration to Bulgaria. Economic Studies, 27(2). https://www.iki.bas.bg/Journals/EconomicStudies/ 2018/20182/5_Bakalova_f-f.pdf

Boccagni, P. (2011). Migrants' social protection as a transnational process:

Public policies and emigrant initiative in the case of Ecuador. International Journal of Social Welfare, 20, 318-325.

Byron, M. \& Condon, S. (1996). A comparative study of Caribbean return migration from Britain and France: towards a context-dependent explanation. Transactions of the Institute of British Geographers NS 21(1), 91-104. https://www.jstor.org/stable/622927

Callea, S. (1986). Different forms, reasons and motivations for return migration of persons who voluntarily decide to return to their countries of origin. International Migration 24, 61-76.

Cerase, F. P. (1974). Expectations and reality: a case study of return migration from the United States to Southern Italy. International Migration Review, 8(2), 245-62.

Cheianu-Andrei, D. (2013). Cartografierea diasporei moldovenești în Italia, Portugalia, Franța şi Regatul Unit al Marii Britanii. In: Ciclul de studii "Cartografierea diasporei moldovenești” II, Organizația Internaţională pentru Migrație, Misiunea în Moldova în cadrul proiectului UE-OIM, "Susținerea implementării componentei de migrație și dezvoltare a Parteneriatului de mobilitate UE-Moldova".

Dustmann, C. (2001). Return migration, wage differentials, and the optimal 
migration duration. [Discussion Paper No. 264]. Bonn: Institute for the Study of Labor.

Dustmann, C., Weiss, Y. (2007). Return Migration: Theory and Empirical Evidence from the UK. British Journal of Industrial Relations, 45(2), 236-256

Gmelch, G. (1980). Return migration. Annual Review of Anthropology, 9(1), 135-159.

Hachi, M., Morozan S. Migrația de revenire. În. //Managementul demografic (în baza studiilor din republica Moldova). Coord. Matei, C., Sainsus V., Hachi, M. Chișinău, 2021. 142-147.

ILO, (2017) Migrant Workers: The Case of Moldova. http://www.ilo.org/ wcmsp5/groups/public/ed_protect/rotrav/migrant/documents/publicati on/wcms_613508.pdf

Ivanova, V. (2015). Return policies and (r)emigration of Bulgarians in the preand post-accession period, Problemy Polityki Spoïecznej. Studia $i$ Dyskusje, 31(4). http://www.problemypolitykispolecznej.pl/ Returnpolicies-and-r-emigration-of-Bulgarians-nin-the-pre-and-postaccession-period, 122911.

King, R., ed. (1986). Return Migration and Regional Economic Problems. London: Croom Helm.

King, R. (2000). Generalizations from the history of return migration. In: Return migration:Journey of hope or despair. Geneva: IOM.

Matei, C., Sainsus, V., Hachi, M. (2021), Managementul demografic (în baza studiilor din Republica Moldova). Chisinau, Arpoligraf, 2021, 147 p.

Morcotîlo, I. (2014). Aspectul migrațional în securitatea economică a Republicii Moldova: Analiză instituțională. Expert-Grup, Chișinău.

Moșneaga, V. (2017). Migrație și dezvoltare: Aspecte politico-juridice, Chişinău.

OECD (2008), Return Migration: A New Perspective. https://www.oecd.org/ migration/mig/43999382.pdf

Popova, N., Bardak, U., Monteleone, C., Alquezar, J., Panzica, F (2007). The contribution of human resources development to migration policy in Moldova, ETF working paper, 2007. https://www.etf.europa.eu/ sites/default/files/m/C12578310056925BC12573DB004D3B74_NOT E84CGJU.pdf

Ravenstein, E. G. (1885). The laws of migration. Journal of the Royal Statistical Society, 48, 167-235, 52, 241-305.

Riiskjaer, M. \& Nielsson, T. (2008). Circular repatriation: The unsuccessful return and reintegration of Iraqis with refugee status in Denmark. New issues in refugee research paper no. 165. Geneva: UNHCR.

Stark, O. (1991). The Migration of Labor. Cambridge: Basil Blackwell. 
Stark, O. (1996). On the microeconomics of return migration Occasional Papers No. 1/1996). Vienna: University of Vienna, Center for International and Interdisciplinary Studies.

Stefannson, A. (2006). Homes in the making: Property restitution, refugee return, and senses of belonging in a post-war Bosnian town. International Migration, 44(3), 115-139.

Todaro, M. P. (1969). A model of labor migration and urban unemployment in less developed countries. The American Economic Review, 59(1), 138-48.

Vremiș, M. ș.a. (2014), Reîntoarcerea lucrătorilor migranți și dezvoltarea socio-economică a Republicii Moldova. International Labour Organization (DWT/CO-Budapest). Budapest: ILO, 2014. https://brd.gov.md/sites/default/files/document/

attachments/06_studiu_ilo_reintoarcerea_lucratorilor_migranti_si_des voltarea_rm_2014_rom.pdf

Zwania-Rößler, I., \& Ivanova, V. (Eds.) (2013). Welcome home? Challenges and chances of return migration. Washington, DC: Transatlantic Forum on Migration and Integration.

UNDESA, (1998). Recommendations on Statistics of International Migration Revision 1. United Nations: New York. https://unstats.un.org/ unsd/publication/SeriesM/SeriesM_58rev1E.pdf

Acknowledgement: This article was elaborated within the project Jean Monnet Chair in EU Studies and Migration, implemented with support of the ERASMUS+ programme of the European Union (ref. nr. 620774-EPP-1-2020-1-MD-EPPJMOCHAIR). The support granted by the European Commission for the elaboration of this publication is not a content approval, which only reflects the opinions of the authors, and the Commission can not be held accountable for any use of the information contained in this. 